\title{
Carbamino Group Formation with Peptides and Proteins Studied by Mass Spectrometry
}

\author{
Peran Terrier* and D. J. Douglas \\ Department of Chemistry, University of British Columbia, Vancouver, British Columbia, Canada
}

At high $\mathrm{pH}$ and in the presence of dissolved $\mathrm{CO}_{2}$, the $\mathrm{N}$-terminus and $\varepsilon$-amino groups of amino acids, peptides, and proteins can form carbamino adducts with $\mathrm{CO}_{2}, \mathrm{R}_{-} \mathrm{NH}_{2}+\mathrm{CO}_{2} \leftrightarrow$ $\mathrm{R}-\mathrm{NHCOO}^{-}+\mathrm{H}^{+}$. We report the first study of carbamino group formation by electrospray ionization (ESI) mass spectrometry (MS). Angiotensin II, bradykinin, substance P, and insulin have been studied. A careful optimization of the instrumental parameters was necessary to allow the transfer of the fragile adducts into vacuum for mass analysis. Particularly, dissociation of the adducts in the ion sampling process and $\mathrm{pH}$ changes in ESI must be minimized. With these precautions, levels of carbamino group formation of angiotensin II and bradykinin determined from mass spectra agree with those expected to be in solution, calculated from literature equilibrium constants. Thus, ESI MS can quantitatively measure ratios of carbamino adduct to total peptide concentration in solution. Values of equilibrium constants for carbamino group formation with substance $\mathrm{P}\left(\mathrm{pK}_{\mathrm{c}}=4.77 \pm 0.18\right)$ and insulin $\left(\mathrm{pK}_{\mathrm{c}}=4.99 \pm 0.05\right)$ are reported for the first time. (J Am Soc Mass Spectrom 2010, 21, 1500-1505) (c) 2010 American Society for Mass Spectrometry

$\mathrm{A}$ thigh $\mathrm{pH}$ and in the presence of dissolved $\mathrm{CO}_{2}$, the $\mathrm{N}$-terminus and $\varepsilon$-amino groups of amino acids, peptides, and proteins can form adducts with $\mathrm{CO}_{2}$, known variously as carbamino groups, carbamino acids, carbamates, carbamides, or carbo amino groups [1]. The reaction is governed by four simultaneous equilibria:

$$
\begin{aligned}
& \mathrm{R}-\mathrm{NH}_{3}^{+} \leftrightarrow \mathrm{R}_{-} \mathrm{NH}_{2}+\mathrm{H}^{+} \\
& \mathrm{K}_{\mathrm{Z}}=\frac{\left[\mathrm{R}-\mathrm{NH}_{2}\right]\left[\mathrm{H}^{+}\right]}{\left[\mathrm{R}-\mathrm{NH}_{3}^{+}\right]} \\
& \mathrm{R}-\mathrm{NH}_{2}+\mathrm{CO}_{2} \leftrightarrow \mathrm{R}-\mathrm{NHCOO}^{-}+\mathrm{H}^{+} \\
& \mathrm{K}_{\mathrm{C}}=\frac{[\mathrm{R}-\mathrm{NHCOO}]\left[\mathrm{H}^{+}\right]}{\left[R-\mathrm{NH}_{2}\right]\left[\mathrm{CO}_{2}\right]} \\
& \mathrm{CO}_{2}+\mathrm{H}_{2} \mathrm{O} \leftrightarrow \mathrm{HCO}_{3}^{-}+\mathrm{H}^{+} \\
& \mathrm{K}_{1}^{\prime}=\frac{\left[\mathrm{HCO}_{3}^{-}\right]\left[\mathrm{H}^{+}\right]}{\left[\mathrm{CO}_{2}\right]} \\
& \mathrm{HCO}_{3}^{-} \leftrightarrow \mathrm{CO}_{3}^{2-}+\mathrm{H}^{+} \\
& K_{3}^{\prime}=\frac{\left[\mathrm{CO}_{3}^{2-}\right]\left[\mathrm{H}^{+}\right]}{\left[\mathrm{HCO}_{3}^{2-}\right]}
\end{aligned}
$$

Address reprint requests to D. J. Douglas, Department of Chemistry, University of British Columbia, 2036 Main Mall, Vancouver, BC, V6T 1Z1, Canada. E-mail: douglas@chem.ubc.ca

*Current address: Adocia, 115 Avenue Lacassagne, 69003 Lyon, France. where $K_{z}$ is the acid dissociation equilibrium constant for the amino group, $K_{c}$ is the association equilibrium constant for formation of the carbamino adduct (including the dissociation of the carbamic acid), $K_{1}^{\prime}$ is the equilibrium constant for the hydration of $\mathrm{CO}_{2}$ and its dissociation to bicarbonate, and $K_{2}^{\prime}$ is the equilibrium constant for the dissociation of bicarbonate to carbonate [2].

The formation of carbamino groups alters the electrostatic properties of peptides and proteins and can have many different effects. For example, carbamino groups can change peptide conformation [3], influence peptide degradation and receptor binding [2], and increase the neurotoxicity of amino acids [4]. Carbamino groups increase the stability of insulin dimers [5] and are required for metal binding at the active sites of ribulose1,5-biphosphate carboxylase oxygenase (RUBISCO) [6] and urease [7]. Carbamino group formation at the Ntermini changes the oxygen binding properties of hemoglobin [8-12] and allows hemoglobin to transport carbon dioxide [13-15]. Nearly any peptide or protein that does not have the N-terminus blocked is subject to the formation of carbamino groups [2, 16-18].

To react with $\mathrm{CO}_{2}$, the amine must be in its neutral form (equilibrium 2). Therefore, a relatively high $\mathrm{pH}$, determined by $\mathrm{pK}_{\mathrm{z}}$ (equilibrium1), is required. Peptides and proteins have lower values of $\mathrm{pK}_{\mathrm{z}}(7-8)$ than amino acids (ca. 9) and thus carbamino groups can be formed at lower $\mathrm{pH}(7-8)$. In addition, the N-terminus of a protein generally has a lower $\mathrm{pK}_{\mathrm{z}}(7-8)$ than lysine side chains $\left(\mathrm{pK}_{\mathrm{z}}=9-12\right)$, and thus more readily forms carbamino adducts near $\mathrm{pH}=8.0$ The concentration of $\mathrm{CO}_{2}$ available for the formation of the carbamino adduct depends on the $\mathrm{pH}$ and the concentration of bicarbonate (equilibria 3 and 4 ). Because $\mathrm{K}_{2}^{\prime}=1.74 \times$ 
$10^{-10}\left(\mathrm{pK}_{2}^{\prime}=9.76\right)$, dissociation of bicarbonate to carbonate is negligible at $\mathrm{pH}<8$. If the peptide/protein concentration is low compared to the bicarbonate concentration, the concentration of dissolved $\mathrm{CO}_{2}$ can be estimated from equilibrium $3\left(\mathrm{~K}_{1}^{\prime}=6.61 \times 10^{-7}, \mathrm{pK}_{1}^{\prime}=\right.$ 6.18) [2]. For example, at $\mathrm{pH}=7,\left[\mathrm{HCO}_{3}^{-}\right] /\left[\mathrm{CO}_{2}\right]=6.6$. At higher $\mathrm{pH}$, this ratio increases, and the concentration of $\mathrm{CO}_{2}$ decreases.

By combining equilibria $1-3$, one can relate $\mathrm{K}_{\mathrm{c}}, \mathrm{K}_{1}^{\prime}$, $\mathrm{K}_{\mathrm{z}},\left[\mathrm{H}^{+}\right]$, the total amine concentration $\left(\mathrm{TA}=\left[\mathrm{RNH}_{2}\right]+\right.$ $\left.\left[\mathrm{RNH}_{3}^{+}\right]+\left[\mathrm{RNHCO}_{2}^{-}\right]\right)$, the total bicarbonate concentration $\left(\mathrm{TC}=\left[\mathrm{CO}_{2}\right]+\left[\mathrm{HCO}_{3}^{-}\right]+\left[\mathrm{RNHCO}_{2}^{-}\right]\right)$and the mole fraction of adduct $\left(\mathrm{Z}=\left[\mathrm{RNHCO}_{2}^{-}\right] / \mathrm{TA}\right)$ by [2]

$$
K_{c}=\frac{Z\left(K_{Z} K_{1}^{\prime}+\left(K_{1}^{\prime}+K_{Z}\right)\left[H^{+}\right]+\left[H^{+}\right]^{2}\right)}{K_{Z}\left(Z^{2}(T A)-Z(T C+T A)+(T C)\right)}
$$

From eq 5, at a given $\mathrm{pH}, \mathrm{K}_{\mathrm{c}}$ can be calculated from a measured $Z$ value, or a $Z$ value can be calculated from a known $\mathrm{K}_{\mathrm{c}}$ value. For example, at $\mathrm{pH} 8$, in $20 \mathrm{mM}$ $\mathrm{HCO}_{3}^{-}$, with angiotensin $\mathrm{II},\left(\mathrm{pK}_{\mathrm{z}}=7.55\right.$ and $\mathrm{pK}_{\mathrm{c}}=4.80$ [2]), $\mathrm{Z}=0.26$.

Carbamino group formation has been studied with glycine [3] and other amino acids [4], bradykinin [2], and angiotensin [2], substance P [18], insulin [5], myoglobin $(\mathrm{Mb})[3,19,20]$, and hemoglobin $(\mathrm{Hb})[8-15,21$, 22]. With proteins such as $\mathrm{Mb}$ and $\mathrm{Hb}$, side-chain $\varepsilon$-amino groups can also form carbamino acids. These have higher $\mathrm{pK}_{\mathrm{z}}$ values (typically 8.7-12) [23] than the N-terminus, but carbamino acid formation with $\varepsilon$-amino groups of $\mathrm{Mb}$ [19] and $\mathrm{Hb}$ [24] has been seen in NMR studies. Individual residues could not be resolved, but with $\mathrm{Hb}$ at $\mathrm{pH} 8.5$, up to $70 \%$ of the carbamino group formation was assigned to $\varepsilon$-amino groups [24].

Formation of carbamino groups has been studied mostly by NMR and various titrimetric methods. In this work, we report the first study of the formation of carbamino groups by electrospray ionization (ESI) mass spectrometry (MS). Bradykinin, angiotensin II, substance $\mathrm{P}$, and insulin have been studied. The equilibrium constants for formation of carbamino groups with the N-termini of angiotensin II and bradykinin have been measured by NMR [2] and are shown in Table 1. We find that despite the high bicarbonate concentrations (20-200 mM) necessary for these experiments, it is possible to record useful ESI spectra and measure ratios of carbamino adduct to free peptide. We show that changes in $\mathrm{pH}$ in ESI of sprayed solutions must be minimized, and that the carbamino bond is relatively labile, and so care must be taken to avoid dissociation of

Table 1. Equilibrium constants for the formation of carbamino groups with angiotensin II and bradykinin (from [2])

\begin{tabular}{lcc}
\hline & $\mathrm{pK}_{\mathrm{z}}$ & $\mathrm{pK}_{\mathrm{c}}$ \\
\hline \hline Angiotensin II & $7.55 \pm 0.05$ & $4.80 \pm 0.10$ \\
Bradykinin & $7.14 \pm 0.05$ & $5.02 \pm 0.10$ \\
\hline
\end{tabular}

the $\mathrm{CO}_{2}$ adducts in the ion sampling region of the mass spectrometer. With these precautions, levels of adducts to angiotensin and bradykinin agree with calculations from the literature values of $\mathrm{pK}_{\mathrm{c}}$ and $\mathrm{pK}_{\mathrm{z}}$. Thus, ESI-MS can be used to quantitatively measure levels of carbamino adducts in solution. Values of $\mathrm{pK}_{\mathrm{c}}$ for substance $\mathrm{P}$ and insulin are determined for the first time.

\section{Experimental}

Acetic acid, ammonium hydroxide, ammonium acetate, ammonium bicarbonate, angiotensin II (Asp-Arg-ValTyr-Ile-His-Pro-Phe, $M_{\mathrm{r}}=1046.2 \mathrm{Da}$ ), bradykinin (ArgPro-Pro-Gly-Phe-Ser-Pro-Phe-Arg, $\left.M_{\mathrm{r}}=1060.2 \mathrm{Da}\right)$, substance P (Arg-Pro-Lys-Pro-Gln-Gln-Phe-Gly-Leu-Met$\left.\mathrm{NH}_{2}, M_{\mathrm{r}}=1347.6 \mathrm{Da}\right)$, and porcine insulin dimer $\left(M_{\mathrm{r}}=\right.$ $5778.4 \mathrm{Da})$ were from Sigma-Aldrich, Vancouver, BC, Canada. Nitrogen, UHP-grade, manufacturer's stated purity 99.999\%, was from Praxair, Vancouver, BC, Canada.

Solutions were $20 \mu \mathrm{M}$ peptide or protein in 20 to 180 $\mathrm{mM}$ ammonium acetate or ammonium bicarbonate (water/methanol 90/10 vol/vol). The $\mathrm{pH}$ was measured with an Accumet model $15 \mathrm{pH}$ meter (Fisher Scientific, Nepean, ON, Canada) and adjusted to 7.0 or 8.0 with ammonium hydroxide or acetic acid. The concentration of $\mathrm{CO}_{2}$ in solution was controlled at a given $\mathrm{pH}$ by the concentration of bicarbonate (equilibrium 3). Solutions were not degassed. All experiments were done with solutions at room temperature, $22 \pm$ $2{ }^{\circ} \mathrm{C}$. The equilibrium pressure of $\mathrm{CO}_{2}$ above an aqueous solution of $\mathrm{CO}_{2}$ is given by $\mathrm{P}_{\mathrm{CO} 2}=\mathrm{K}_{\mathrm{H}} \mathrm{x}_{\mathrm{CO} 2}$ where $\mathrm{x}_{\mathrm{CO} 2}$ is the mole fraction of $\mathrm{CO}_{2}$ in solution, and $\mathrm{K}_{\mathrm{H}}$ is Henry's constant. At $22^{\circ} \mathrm{C}, \mathrm{K}_{\mathrm{H}}=1.14 \times 10^{6}$ Torr $\left(\right.$ or $\mathrm{K}_{\mathrm{H}}=$ $26.6 \mathrm{~atm} \mathrm{M}{ }^{-1}$ ) [25]. The concentration of dissolved $\mathrm{CO}_{2}$ in equilibrium with atmospheric $\mathrm{CO}_{2}\left(\mathrm{P}_{\mathrm{CO} 2}=3.3 \times 10^{-4}\right.$ atm) is calculated to be $1.1 \times 10^{-5} \mathrm{M}$, considerably less than the concentrations of $\mathrm{CO}_{2}\left(3.0 \times 10^{-4}\right.$ to $2.2 \times 10^{-3}$ $\mathrm{M})$ estimated from equilibrium 3 with bicarbonate $20-180$ $\mathrm{mM}$ as used here. These calculated concentrations of $\mathrm{CO}_{2}$ give equilibrium partial pressures of $\mathrm{CO}_{2}$ of $8.0 \times 10^{-3}$ to $5.9 \times 10^{-2} \mathrm{~atm}$. Thus $\mathrm{CO}_{2}$ should come out of solution. Nevertheless, solutions were found to give stable ratios of carbamino intensity to free peptide peak intensity for at least $2 \mathrm{~d}$ after preparation, presumably because of the low rate of diffusion of $\mathrm{CO}_{2}$ out of solution. (The diffusion coefficient of $\mathrm{CO}_{2}$ in water at $295 \mathrm{~K}$ is $1.76 \times 10^{-5} \mathrm{~cm}^{2} \mathrm{~s}^{-1}$ [26]; the time for $\mathrm{CO}_{2}$ to diffuse $1 \mathrm{~cm}$ is ca. $8 \mathrm{~h}$ ).

A home-built ESI triple quadrupole mass spectrometer described previously [27-29] and modified to increase sensitivity was used. Samples are infused into an ESI source with a syringe pump (Harvard Apparatus, Holliston, MA, USA) at $0.5-5 \mu \mathrm{L} / \mathrm{min}$. Ions formed by pneumatically-assisted electrospray (sprayer voltage = $4500 \mathrm{~V}$ ) pass through a $2.4 \mathrm{~mm}$ diameter aperture in a curtain plate $(800 \mathrm{~V})$, a dry nitrogen gas, an ion sampling orifice $(0.25 \mathrm{~mm}$ diameter) $(200-400 \mathrm{~V})$, into a region with a background pressure of 0.6 Torr, through a skimmer (aperture diameter $2.90 \mathrm{~mm})(150 \mathrm{~V})$, into a quadrupole ion guide Q0 $\left(9 \times 10^{-3}\right.$ Torr, $\left.\mathrm{N}_{2}\right)$ (offset $=$ 
120-150 V), through a short radio frequency (rf) quadrupole [30] (offset $=100 \mathrm{~V}$ ), into a mass analyzing quadrupole Q1 (offset $=117 \mathrm{~V}$ ). A collision cell with a quadrupole ion guide, $\mathrm{Q} 2$ (offset $=108 \mathrm{~V}$ ), and another quadrupole Q3 (offset $=90 \mathrm{~V}$ ), follow Q1. Quadrupoles Q2 and Q3 were operated in rf only mode as ion guides. Ion counting was used for detection.

\section{Results and Discussion}

\section{Angiotensin II and Bradykinin}

Figure 1 shows mass spectra of angiotensin II (Figure 1a) and bradykinin (Figure $1 \mathrm{~b}$ ) in $20 \mathrm{mM}$ ammonium acetate (plain lines) and in $20 \mathrm{mM}$ ammonium bicarbonate (dashed lines), at $\mathrm{pH}=8.0$. Only doubly charged peptide ions are seen with either salt (ammonium acetate or ammonium bicarbonate). In the presence of $20 \mathrm{mM}$ bicarbonate, adduct peaks higher in $\mathrm{m} / \mathrm{z}$ by $22 \mathrm{Th}$, corresponding to a mass increase of $44 \mathrm{Da}$ are seen, in addition to the free peptide peaks. The carbamino group is expected to be in the negatively charged carboxyl form at $\mathrm{pH}$ 8.0, which would give a mass increase of 43 and a shift to the +1 charge state, neither of which are seen. Apparently, the negative carboxyl group recombines in ESI. The adduct ion abundance increased with bicarbonate concentration, as expected from equilibrium 2 (see below).

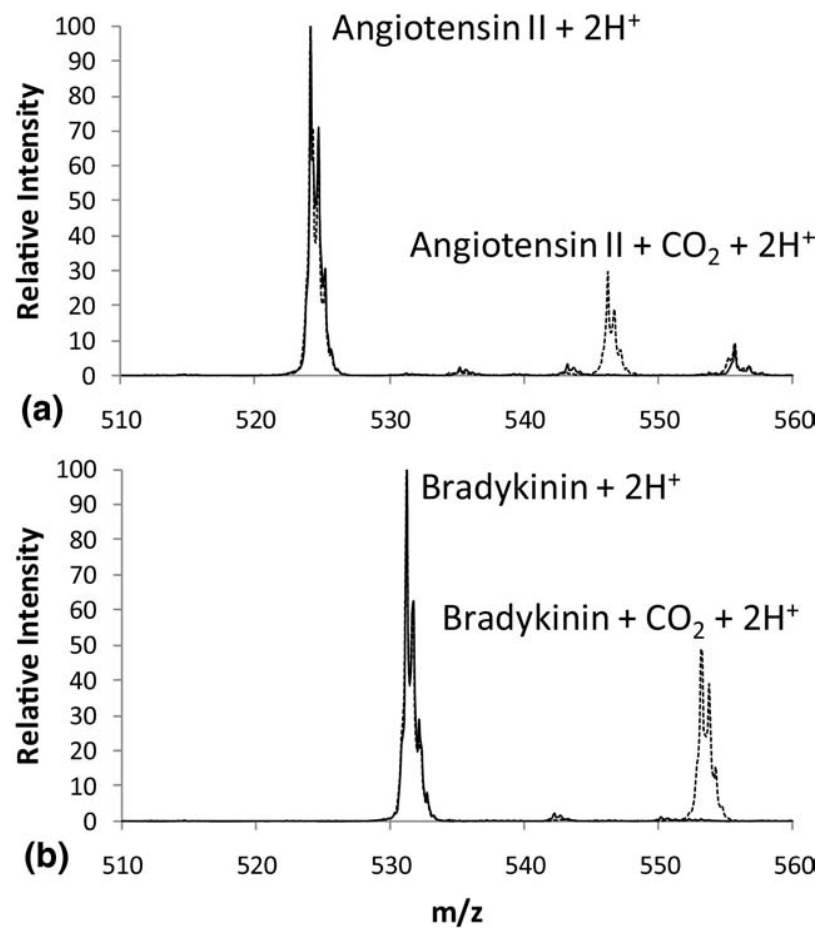

Figure 1. Mass spectra of $20 \mu \mathrm{M}$ (a) angiotensin II and (b) bradykinin in $20 \mathrm{mM}$ ammonium acetate (plain lines) and $20 \mathrm{mM}$ ammonium bicarbonate (dashed lines) (water/methanol 90/10 $\mathrm{vol} / \mathrm{vol}, \mathrm{pH}=8.0)$.

\section{Effects of Operating Conditions}

The observed carbamino ion abundance, i.e., the ratio of carbamino peak intensity to total peptide peak intensity, $\left(\mathrm{RNHCOOH}+2 \mathrm{H}^{+}\right) /\left(\left(\mathrm{RNHCOOH}+2 \mathrm{H}^{+}\right)+\right.$ $\left.\left(\mathrm{RNH}_{2}+2 \mathrm{H}^{+}\right)\right)$, depends on the operating conditions. The effects of sprayer flow rate (Figure $2 \mathrm{a}$ ), orificeskimmer voltage difference (Figure $2 b$ ) and skimmerQ0 offset voltage difference (Figure 2c) on the carbamino ion abundance of bradykinin were investigated. Similar effects were seen with angiotensin II, substance $P$, and insulin.

Figure 2a shows that the observed level of adduct remains constant for solution flow rates above about 3 $\mu \mathrm{L} / \mathrm{min}$. At lower flow rates the observed level of adduct decreases with decreasing flow rate. This may be due to a decrease of the $\mathrm{pH}$ of the sprayed solution. When positive ions are formed in ESI, excess protons are forced into the sprayed solution or formed by electrolytic production, lowering the $\mathrm{pH}$ [31]. This change in $\mathrm{pH}$ increases as the flow rate decreases. A change of $\mathrm{pH}$ from 8.0 to 7.0 can cause the calculated ratio in solution $\left[\mathrm{RNHCOO}^{-}\right] /\left(\left[\mathrm{RNHCOO}^{-}\right]+\left[\mathrm{RNH}_{2}\right]+\right.$ $\left[\mathrm{RNH}_{3}^{+}\right]$) to decrease by $\times 2$ because of a greater degree of protonation of the N-terminus (a decrease of $\mathrm{pH}$ by 1 causes $\left[\mathrm{H}^{+}\right]$to increase by $\times 10$, but also $\left[\mathrm{CO}_{2}\right]$ to increase $\times 10$ (equilibrium 3 ). These effects are offsetting). This change is well within the range calculated to occur in ESI [31].

Figure $2 b$ shows the effect of the orifice-skimmer voltage difference on the abundance of the bradykinin carbamino adduct ion. Voltage differences above about $150 \mathrm{~V}$ cause the abundance of the adduct ion to decrease. This decrease is attributed to dissociation of the carbamino bond by ion activation in the orifice-skimmer region of the mass spectrometer. Under the conditions where the carbamino bond is dissociated, no additional dissociation of the peptide is seen, indicating that the carbamino bond is weaker than a peptide bond.

Figure $2 c$ shows that as the voltage difference between the skimmer and the offset of Q0 increases, the abundance of the adduct ion decreases. This decrease is also attributed to dissociation of the carbamino bond through ion activation by collisions in Q0, analogous to the injection of ions into the collision cell of a triple quadrupole system.

\section{Effect of Bicarbonate Concentration}

Based on the results of Figure 2, the solution flow rate was set to $5 \mu \mathrm{L} / \mathrm{min}$, the orifice-skimmer voltage difference was set to $75 \mathrm{~V}$, and the skimmer-Q0 voltage difference was set to $16 \mathrm{~V}$. These conditions gave reasonable sensitivity and, most importantly, preserved the $\mathrm{CO}_{2}$ adducts. The intensities of the adduct ion peaks and the free peptide ion peaks were measured at different bicarbonate concentrations. Figure 3 shows the ratio of carbamino peak intensity to the total intensity of the peptide peaks for angiotensin II (Figure 3a) and 


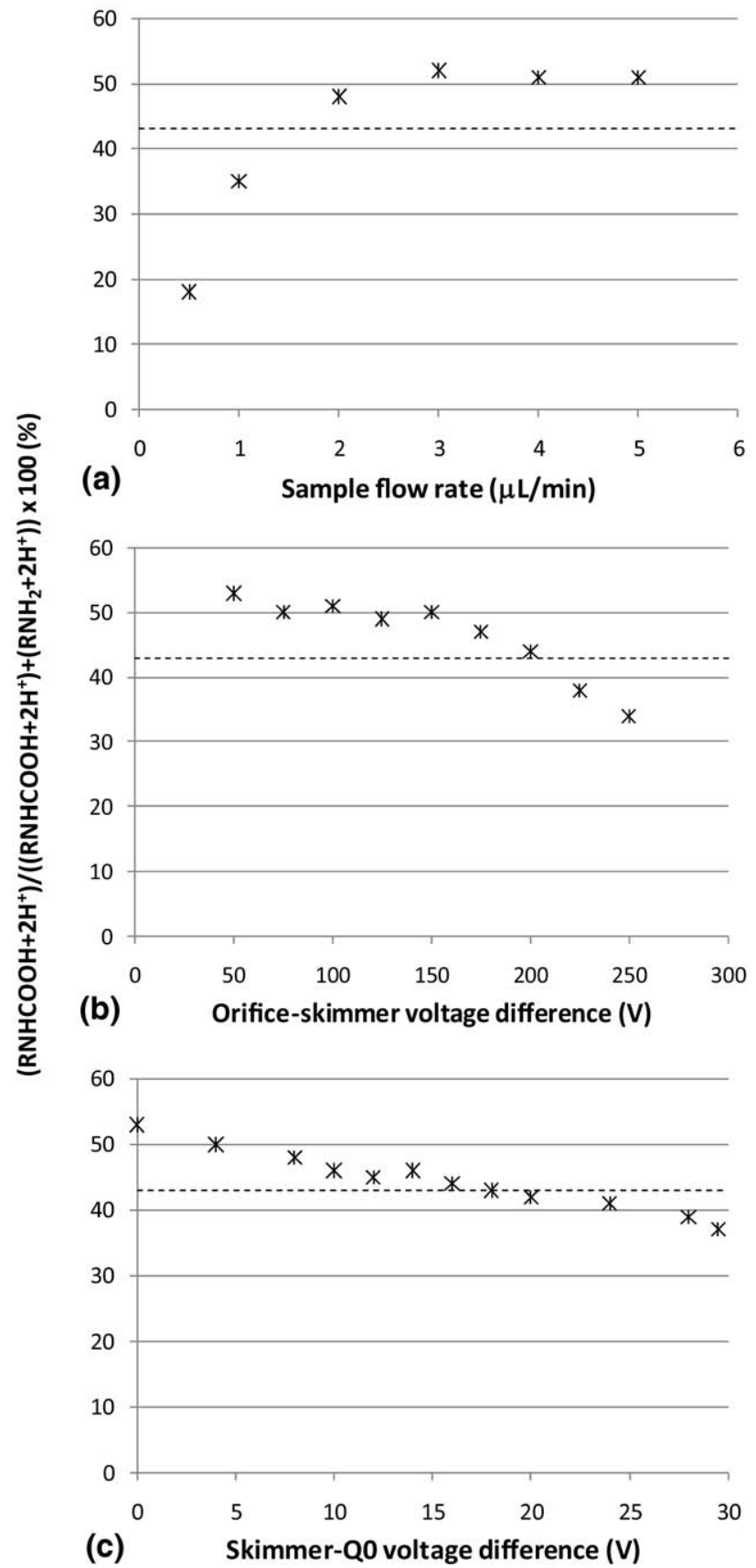

Figure 2. Ratios of intensities ( $\left.\mathrm{RNHCOOH}+2 \mathrm{H}^{+}\right) /((\mathrm{RNHCOOH}+$ $\left.\left.2 \mathrm{H}^{+}\right)+\left(\mathrm{RNH}_{2}+2 \mathrm{H}^{+}\right)\right)$versus (a) sample flow rate, (b) voltage difference between the orifice and skimmer, and (c) voltage difference between the skimmer and Q0 for $20 \mu \mathrm{M}$ bradykinin in $60 \mathrm{mM}$ ammonium bicarbonate (water/methanol 90/10 vol/vol, $\mathrm{pH} 8.0$ ). Dashed lines: concentration ratio in solution, $Z$, calculated from eq 5 using the equilibrium constants of Table 1.

bradykinin (Figure $3 b$ ) versus bicarbonate concentration. The solid lines show the concentration ratios in solution, $\mathrm{Z}$, calculated from eq 5 using the equilibrium constants $\left(\mathrm{pK}_{\mathrm{z}}\right.$ and $\left.\mathrm{pK}_{\mathrm{c}}\right)$ of Table 1. The dashed lines show the highest and lowest ratios calculated from the combined uncertainties of the values of $\mathrm{pK}_{\mathrm{c}}$ and $\mathrm{pK}_{\mathrm{z}}$ (Table 1). For ammonium bicarbonate concentrations higher than $20 \mathrm{mM}$, the observed ratios agree within
$20 \%$ with ratios calculated from the literature $\mathrm{pK}_{\mathrm{c}}$ values. Conversely, the $K_{c}$ values of angiotensin and bradykinin determined from these ratios, $[(1.10 \pm 0.10) \times$ $10^{-5}$ and $(1.15 \pm 0.22) \times 10^{-5}$ respectively], agree with the literature $K_{c}$ values $\left[(1.56 \pm 0.3) \times 10^{-5}\right.$ and $(9.55 \pm$ $0.2) \times 10^{-6}$ respectively], within about $25 \%$. The corresponding average $\mathrm{pK}_{\mathrm{c}}$ value for each peptide calculated from ratios of carbamino peak to total peptide peaks for each bicarbonate concentration agree within 3\% with the literature values. Thus, ESI-MS can quantitatively measure the ratio of carbamino adduct concentration to total peptide concentration in solution, provided $\mathrm{pH}$ changes in ESI and dissociation of the adducts in the ion sampling process are minimized.

\section{Substance $P$ and Insulin}

We have also observed carbamino group formation with substance $\mathrm{P}$ and insulin. Carbamino group formation on the $\alpha$-amino groups (N-termini) of substance $\mathrm{P}$ [18] and insulin [5] has been observed previously by $\mathrm{NMR}$, but values of $\mathrm{pK}_{\mathrm{c}}$ have not been reported.

Figure 4 shows the mass spectra of $20 \mu \mathrm{M}$ substance $P$ in $20 \mathrm{mM}$ ammonium acetate (plain line) and in $20 \mathrm{mM}$

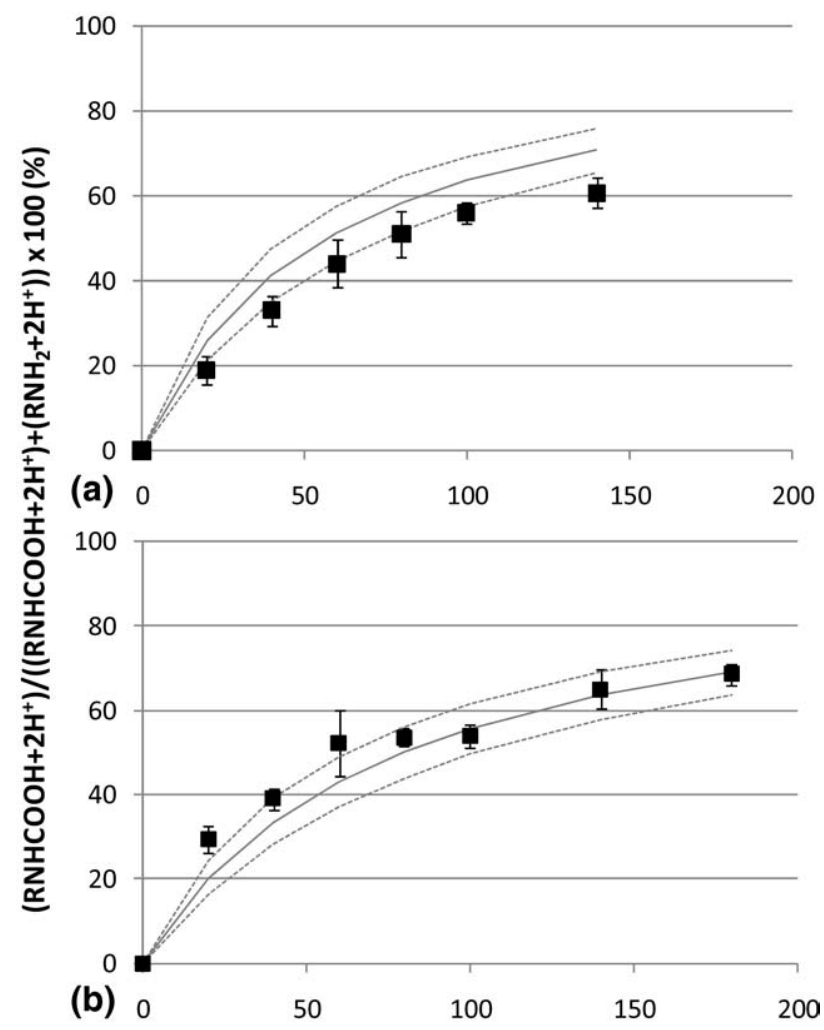

Ammonium bicarbonate concentration ( $\mathrm{mM}$ )

Figure 3. Ratios of intensities $\left(\mathrm{RNHCOOH}+2 \mathrm{H}^{+}\right) /((\mathrm{RNHCOOH}+$ $\left.\left.2 \mathrm{H}^{+}\right)+\left(\mathrm{RNH}_{2}+2 \mathrm{H}^{+}\right)\right)$for $20 \mu \mathrm{M}(\mathbf{a})$ angiotensin II and (b) bradykinin in ammonium bicarbonate (water/methanol 90/10 vol/ vol, $\mathrm{pH}=8.0$ ) versus ammonium bicarbonate concentration. Filled squares: average values and standard deviations of three measurements. Plain grey lines: values calculated from literature $\mathrm{K}_{\mathrm{z}}$ and $\mathrm{K}_{\mathrm{c}}$; dashed lines: values calculated from the uncertainties of the literature values. 


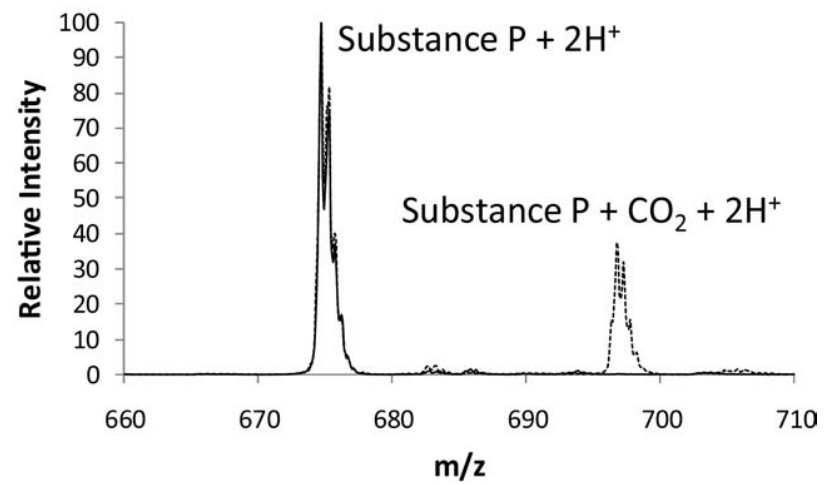

Figure 4. Mass spectra of $20 \mu \mathrm{M}$ substance $\mathrm{P}$ in $20 \mathrm{mM}$ ammonium acetate (plain lines) and $20 \mathrm{mM}$ ammonium bicarbonate (dashed lines) (water/methanol 90/10 vol/vol, $\mathrm{pH}=7.0$ ).

ammonium bicarbonate (dashed line), at $\mathrm{pH}=7.0$. Doubly charged ions dominate the spectra and the adduct corresponding to a mass increase of the peptide ion of 44 $\mathrm{Da}$ is seen, as with bradykinin and angiotensin II.

The mass spectra of $20 \mu \mathrm{M}$ insulin in $23 \mathrm{mM}$ ammonium acetate (plain lines) and in $23 \mathrm{mM}$ ammonium bicarbonate (dashed lines), at $\mathrm{pH}=8.0$ are shown in Figure $5 \mathrm{a}$. Charge states +3 and +4 dominate the spectrum. Figure $5 \mathrm{~b}$ shows a blow-up of the region near the +4 peak in the mass spectrum. In ammonium acetate, a peak corresponding to a mass increase of 17 Da (attributed to an $\mathrm{NH}_{4}^{+}$adduct) can be observed, in addition to the free protein peak. This adduct is also seen with the +3 peak, in a similar proportion. Other minor peaks $(<10 \%)$, presumably corresponding to various salt adducts, are detected. They are neglected in this study. In ammonium bicarbonate, an adduct corresponding to a mass increase of 44 is seen for the free insulin peak and for the $\mathrm{NH}_{4}^{+}$adducts. Only one $\mathrm{CO}_{2}$ adduct is seen. Three residues in insulin can form carbamino adducts near $\mathrm{pH}$ 7.0: $\mathrm{Phe} \mathrm{B} 1, \mathrm{pK}_{\mathrm{z}}=7.2$ [32]; Gly A1, $\mathrm{pK}_{\mathrm{z}}=7.9$ [32]; Lys B29, $\mathrm{pK}_{\mathrm{z}} 7.8$ [32]. Because Phe B1 has the lowest $\mathrm{pK}_{\mathrm{z}}$ it may be responsible for most of the carbamino formation at $\mathrm{pH}=7.0$, but we cannot rule out formation of adducts to Gly A1 or Lys B29.

Figure 6 shows the relative abundance of carbamino ions versus bicarbonate concentration for substance $P$ (Figure 6a) and insulin (Figure 6b). For insulin, the

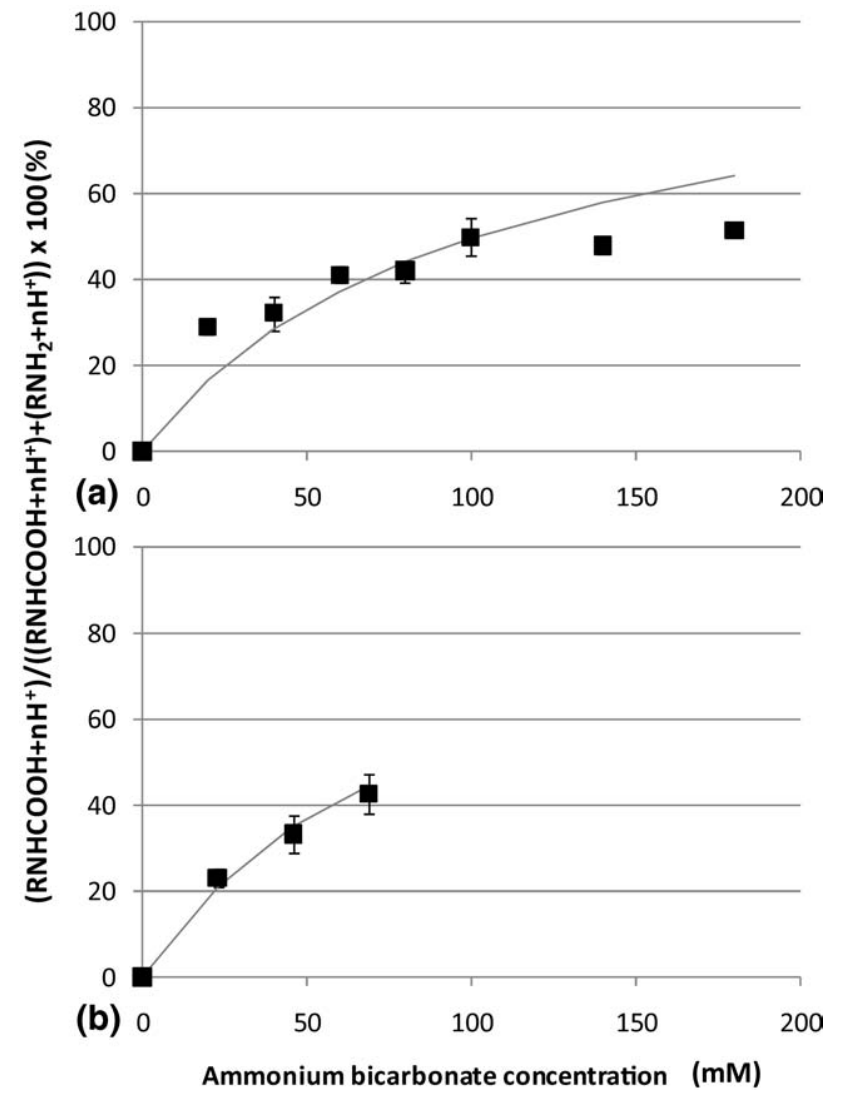

Figure 6. Ratios of intensities $\left(\mathrm{RNHCOOH}+\mathrm{nH}^{+}\right) /((\mathrm{RNHCOOH}+$ $\left.\mathrm{nH}^{+}\right)+\left(\mathrm{RNH}_{2}+\mathrm{nH}^{+}\right)$for $20 \mu \mathrm{M}$ (a) substance $\mathrm{P}$ and (b) insulin in ammonium bicarbonate (water/methanol $90 / 10 \mathrm{vol} / \mathrm{vol}$ ), (a) $\mathrm{pH}=$ 7.0 and $(\mathbf{b}) \mathrm{pH}=8.0$, as a function of ammonium bicarbonate concentration. (a) $n=2$, (b) $n=3$ and 4 . Black squares: average values and standard deviations of three measurements. Grey lines: calculated ratios for $(\mathbf{a}) \mathrm{pK}_{\mathrm{c}}=4.77, \mathrm{pK}_{\mathrm{z}}=7.10$ and $(\mathbf{b}) \mathrm{pK}_{\mathrm{c}}=4.99$, $\mathrm{pK}_{\mathrm{z}}=7.5$.

intensity ratio ( $\mathrm{r}$ ) is measured on background subtracted spectra as follows:

$$
\begin{aligned}
& \sum_{n=3}^{4}\left(\left(\mathrm{RNHCOOH}+n \mathrm{H}^{+}\right)\right. \\
& r=\frac{\left.+\left(\mathrm{RNHCOOH}+\mathrm{NH}_{3}+n \mathrm{H}^{+}\right)\right)}{\sum_{n=3}^{4}\left(\left(\mathrm{RNHCOOH}+n \mathrm{H}^{+}\right)+(\mathrm{RNHCOOH}\right.} \\
& \left.\left.+\mathrm{NH}_{3}+n \mathrm{H}^{+}\right)\right)+\sum_{n=3}^{4}\left(\left(\mathrm{RNH}_{2}\right.\right. \\
& \left.\left.+n \mathrm{H}^{+}\right)+\left(\mathrm{RNH}_{2}+\mathrm{NH}_{3}+n \mathrm{H}^{+}\right)\right)
\end{aligned}
$$
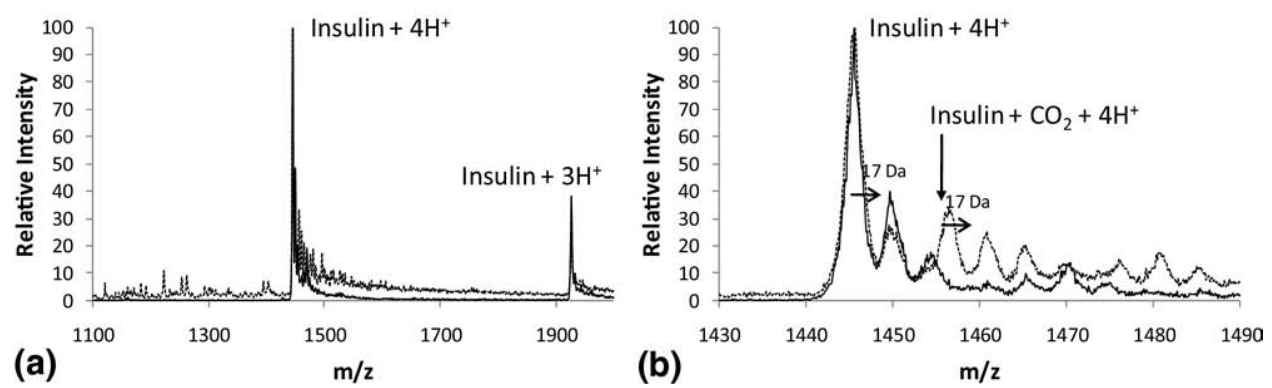

Figure 5. Mass spectra of $20 \mu \mathrm{M}$ insulin in $23 \mathrm{mM}$ ammonium acetate (plain lines) and $23 \mathrm{mM}$ ammonium bicarbonate (dashed lines) (water/methanol 90/10 vol/vol, $\mathrm{pH}=8.0$ ). (a) Full mass range and $(\mathbf{b})+4$ charge state region. 
With insulin the highest carbonate concentration was limited to $69 \mathrm{mM}$. At higher concentrations, the ion intensities were too low to allow useful measurements. From the observed levels of carbamino adducts and the known $\mathrm{pK}_{\mathrm{z}}$ values of substance $\mathrm{P}$ (7.10 [33]) and porcine insulin (7.5, average value between the $\mathrm{pK}_{\mathrm{z}}$ of the two insulin chains: 7.2 and 7.9 [32]) a value of $\mathrm{pK}_{\mathrm{c}}$ can be calculated for each data point. Averaging these values, we determine $\mathrm{pK}_{\mathrm{c}}$ of substance $\mathrm{P}$ is $4.77 \pm 0.18$ and of insulin $4.99 \pm 0.05$. The solid lines in Figure 6 show the ratios calculated from these $\mathrm{pK}_{\mathrm{c}}$ values.

This work shows that ESI-MS offers a new method for the quantitative study of carbamino group formation in peptides and small proteins. In comparison to the NMR and titrimetric methods used previously, smaller amounts of material are required and the measurements can be done more rapidly. Attempts were made to observe carbamino group formation with larger proteins, especially myoglobin. Unfortunately, with the gentle ion sampling conditions needed for this work, the formation of other adducts $\left(\mathrm{Na}^{+}, \mathrm{NH}_{4}^{+}\right.$, bicarbonate) hinders the detection of $\mathrm{CO}_{2}$ adducts. Higher mass resolution, such as provided by ion cyclotron resonance or other mass spectrometers may be required in this case. In the future, it may be possible to study formation of carbamino groups and the binding of metal ions to carbamino groups [34] with larger proteins such as hemoglobin.

\section{Acknowledgments}

The authors acknowledge support for this work by the Natural Sciences and Engineering Research Council through a Discovery Grant.

\section{References}

1. Stadie, C.; O'Brien, H. J. The Equilibrium of Amino Acids, Carbon Dioxide, and Carbamates in Aqueous Solution: with a Note on the Ferguson-Roughton Carbamate Method. J. Biol. Chem. 1936, 112, 723758 .

2. Wittebort, R. J.; Haynes, D. F.; Rothgeb, T. M.; Gurd, R. S. The Quantitation of Carbamino Adduct Formation of Angiotensin II and Bradykinin. Biophys. J. 1978, 24, 765-778.

3. Morrow, J. S.; Keim, P.; Gurd, F. R. N. $\mathrm{CO}_{2}$ Adducts of Certain Amino Acids, Peptides and Sperm Whale Myoglobin Studied by Carbon 13 and Proton Nuclear Magnetic Resonance. J. Biol. Chem. 1974, 249, 7484-7494.

4. Chen, J.-G.; Sandberg, M.; Weber, S. G. Chromatographic Method for the Determination of Conditional Equilibrium Constants for the Carbamate Formation Reaction from Amino Acids and Peptides in Aqueous Solution. J. Am. Chem. Soc. 1993, 115, 7343-7350.

5. Griffey, R. H.; Scavini, M.; Eaton, R. P. Characterization of the Carbamino Adducts of Insulin. Biophys. J. 1988, 54, 295-300.

6. Hartmann, F. C.; Harpel, M. R. Structure, Function, Regulation, and Assembly of D-Ribulose-1,5-Biphosphate Carboxylase/Oxygenase. Annu. Rev. Biochem. 1994, 63, 197-234.

7. Jabri, E.; Carr, M. B.; Hausinger, R. P.; Karplus, P. A. The Crystal Structure of Urease from Klebsiella aerogenes. Science 1995, 268, 998-1004.

8. Kilmartin, J. V.; Rossi-Bernardi, L. Interaction of Hemoglobin with Hydrogen Ions, Carbon Dioxide, and Organic Phosphates. Physiol. Rev. $1973,53,836-890$.
9. Rossi-Bernardi, L.; Roughton, F. J. W. The Specific Influence of Carbon Dioxide and Carbamate Compounds on the Buffer Power and Bohr Effects in Human Hemoglobin Solutions. J. Physiol. 1967, 189, 1-29.

10. Morrow, J. S.; Matthew, J. B.; Wittebort, R. J.; Gurd, F. R. N. Carbon 13 Resonances of ${ }^{13} \mathrm{CO}_{2}$ Carbamino Adducts of $\alpha$ and $\beta$ Chains in Human Adult Hemoglobin. J. Biol. Chem. 1976, 251, 477-484.

11. Kilmartin, J. V. Interactions of Haemoglobin with Protons, $\mathrm{CO}_{2}$, and 2,3-Diphosphoglycerate. Br. Med. Bull. 1976, 32, 209-212.

12. Kilmartin, J. V.; Rossi-Bernardi, L. Inhibition of $\mathrm{CO}_{2}$ Combination and Reduction of the Bohr Effect in Hemoglobin Chemically Modified at its $\alpha$-Amino Groups. Nature 1969, 222, 1243-1246.

13. Ferguson, J. K. W.; Roughton, F. J. W. The Chemical Relationships and Physiological Importance of Carbamino Compounds of $\mathrm{CO}_{2}$ with Hemoglobin. J. Physiol. 1934, 83, 87-102.

14. Ferguson, J. K. W.; Roughton, F. J. W. The Direct Chemical Estimation of Carbamino Compounds of $\mathrm{CO}_{2}$ With Haemoglobin. J. Physiol. 1934, $83,68-86$.

15. Roughton, F. J. W. Some Recent Work on the Interactions of Oxygen, Carbon Dioxide and Haemoglobin. Biochem. J. 1970, 117, 801-812.

16. Rothgeb, T.; England, R. D.; Jones, B. N.; Gurd, R. S. Physical Characterization of S-Methylglucagon Formation and Quantitation of Carbamino Adduct Formation. Biochemistry 1978, 17, 4564-4571.

17. Edsall, J. T.; Wyman, J. Biophysical Chemistry V1, Academic Press: New York, 1958; p. 571-578.

18. Davis, A. J.; Hawkes, G. E.; Haycock, P. R.; O’Brien, P. O.; Kidd, B. I. Mapp, P. I.; Naughton, D.; Grootveld, M. Generation of Substance P Carbamate in Neutral Aqueous Solution. Relevance to Inflammatory Joint Diseases. FEBS Lett. 1993, 329, 249-252.

19. Wittmann, B.; Gros, G. The Carbamate Kinetics of $\alpha$ - and $\varepsilon$-Amino Groups of Myoglobin. J. Biol. Chem. 1981, 256, 8332-8340.

20. Busch, M. R.; Maskalick, D. G.; Neireiter, G. W.; Harris, D. E.; Gurd, F. R. N. Aliphatic Semisynthetic Variants of the Amino-Terminal Residue of Sperm Whale Myoglobin: Enrichment with ${ }^{13} \mathrm{C}$ and Determination and Interpretation of Terminal pK Values. Biochemistry 1985, 24, 6707-6716.

21. Morrow, J. S.; Keim, P.; Visscher, R. B.; Marshall, R. C.; Gurd, F. R. N. Interaction of ${ }^{13} \mathrm{CO}_{2}$ and Bicarbonate with Human Hemoglobin Preparations. Proc. Nat. Acad. Sci. U.S.A. 1973, 70, 1414-1418.

22. Matthew, J. B.; Morrow, J. S.; Wittebort, R. J.; Gurd, F. R. N. Quantitative Determination of Carbamino Adducts of $\alpha$ and $\beta$ Chains of Human Adult Hemoglobin in Presence and Absence of Carbon Monoxide and 2,3-Diphosphoglycerate. J. Biol. Chem. 1977, 252, 2234-2244.

23. Bashford, D.; Case, D. A.; Dalvit, C.; Tennant, L.; Wright, P. E. Electrostatic Calculations of Side-Chain $\mathrm{pK}_{\mathrm{a}}$ Values in Myoglobin and Comparison with NMR Data for Histidine. Biochemistry 1993, 32, 8045-8056.

24. Gros, G.; Rollema, H. S.; Forster, R. E. The Carbamate Equilibrium of $\alpha-$ and $\varepsilon$-Amino Groups of Hemoglobin at $37^{\circ} \mathrm{C}$. J. Biol. Chem. 1981, 256 5471-5480.

25. Quinn, E. L.; Jones, C. L. Carbon Dioxide; Reinhold Publishing Corp.: New York, 1936, p. 94.

26. Tamimi, A.; Rinker, E. B.; Sandall, O. C. Diffusion Coefficients for Hydrogen Sulfide, Carbon Dioxide, and Nitrous Oxide in Water Over the Temperature Range 293 K-368 K. J. Chem. Eng. Data 1994, 39, $330-332$.

27. Hunter, C. L.; Mauk, A. G.; Douglas, D. J. Dissociation of Heme from Myoglobin and Cytochrome $b_{5}$ : Comparison of Behavior in Solution and in the Gas Phase. Biochemistry 1997, 36, 1018-1025.

28. Mauk, M. R.; Mauk, A. G.; Chen, Y. L.; Douglas, D. J. Tandem Mass Spectrometry of Protein-Protein Complexes: Cytochrome $c$ - Cytochrome $b_{5}$. J. Am. Soc. Mass Spectrom. 2002, 13, 59-71.

29. Chen, Y. L.; Collings, B. A.; Douglas, D. J. Collision Cross Sections of Myoglobin and Cytochrome $c$ Ions with Ne, Ar, Kr. J. Am. Soc. Mass Spectrom. 1997, 8, 681-687.

30. Brubaker, W. M. An Improved Quadrupole Mass Analyzer. Adv. Mass Spectrom. 1968, 4, 293-299.

31. Van Berkel, G. J.; Zhou, F.; Aronson, J. T. Changes in Bulk Solution pH Caused by the Inherent Controlled-Current Electrolytic Process of an Electrospray Ion Source. Int. J. Mass Spectrom. Ion Processes 1997, 162, 55-67.

32. Sheffer, M. G.; Kaplan, H. Unusual Chemical Properties of the Amino Groups of Insulin: Implications for Structure-Function Relationship. Can. J. Biochem. 1979, 57, 489-496.

33. Seelig, A. Substance P and Antagonists. Surface Activity and Molecular Shapes. Biochim. Biophys. Acta 1990, 1030, 111-118.

34. Mauk, M. R.; Rosell, F. I.; Mauk, A. G. Metal Ion Facilitated Dissociation of Heme from b-Type heme Proteins. J. Am. Chem. Soc. 2009, 131, $16976-16983$ 